Scientific Bulletin, № 2, 2021, pages 149-153

Yegin Samet Emre, emreygn@ outlook.com

Western Caspian University

DOI: doi.org/10.54414/fqnw3260

e-ISSN: $2789-4614$

\title{
WHAT ARE HIGH EXCITEMENT, SYMPTOMS AND TREATMENTS
}

\section{ABSTRACT}

What is high excitement? What are the symptoms? What are the risk factors? High anxiety types and treatment methods are discussed. By interpreting certain stimuli perceived in the body or in the external environment as threats and dangers and avoiding certain events and situations that accompany them, the symptoms of constant fear, anxiety, anxiety and tension that the person experiences and cannot manage are usually High Anxiety. Disturbances.

Keywords: Psychological, High Anxiety, Mood Disorders, Anxiety

\section{YÜKSӘK HӘYӘCAN, SIMPTOMLAR VӘ MÜALİCOÜSULLARI NəDİR?}

\section{XÜLASə}

Yüksək həyəcan nədir? Simptomları hansılardır? Risk faktorları hansılardır? Yüksək həyəcan növləri və müalicə üsulları müzakirə olunur. İnsanın bədənində və ya xarici mühitdə alqılanan bəzi stimulları təhdid və təhlükə olaraq şərh edərək və onları müşayiət edən bəzi hadisə və vəziyyətlərdən qaçınaraq yaşadığı və idarə edə bilmədiyi daimi qorxu, narahatlıq, narahatliq vo gərginlik əlamətləri ümumiyyətlə yüksək həyəcan pozğunluqlarıdır.

Açar sözlər: psixoloji, yüksək həyəcan, əhval pozuntuları, narahatlıq, anksiyete

\section{ЧТО ТАКОЕ ТРЕВОГА? КАКОВЫ СИМПТОМЫ, ФАКТОРЫРИСКА И МЕТОДЫ ЛЕЧЕНИЯ?}

\section{PEЗЮME}

Что такое сильное волнение? Какие симптомы? Какие факторы риска? Обсуждаются виды повышенной тревожности и методы лечения. Симптомы постоянного страха, беспокойства и напряжения, которые человек испытывает и не может справиться, интерпретируя определенные стимулы, воспринимаемые в теле или во внешней среде как угрозы и опасности, и избегая определенных событий и ситуаций, которые их сопровождают, - это обычно расстройства высокой тревожности.

Ключевые слова: Психология, Сильное беспокойство, расстройства настроения, тревога 
Həm psixoloqların, həm də psixiatrların lazım olduqda müalicə etdikləri ən çox yayılmış əhval pozuntularından biri yüksək həyəcan problemləridir. Yüksək həyəcan problemi, xəstənin gündəlik həyatını qorumaq üçün zehni və davranış funksiyalarını itirməsinə, özünü sosial həyatdan təcrid etməsinə və ya müxtəlif vəsvəsələr və məcburiyyətlər səbəbiylə sosial vəzifələrini yerinə yetirə bilməməsinə səbəb ola bilər.

"Yüksək həyəcan pozğunluqları 5\% ilə 6\% arasındadır. Qadınlarda yayılma nisbəti kişilərdən təxminən iki dəfə çoxdur. Ümumiyyətlə erkən yaşdan başlayır və ortaya çıxması baxımından ən riskli dövr gənc yetkinlik dövrüdür; 15-25 yaş arasındadır. Bununla birlikdə tərbiyə, şəxsiyyət, həyat hadisələri və erkən yaş kimi amillər fərqli dövrlərdə narahatlıq pozuqluqlarının inkişafına səbəb ola bilər.

Bioloji və psixo-sosial səbəblər xəstəliyin inkişafında birlikdə rol oynayır. Xəstəliyin əlamətlərinin genetik ötürülməsinin ətraf mühit faktorlarından da təsirləndiyi düşünülür.

Bəzi elmi işlər; həm də cinsiyyətindən asılı olmayaraq narahatlığa meyl-li bir fizioloji quruluşun mövcudluğundan bəhs edir. [1]

Yüksək həyəcan əlamətləri hansılardır?

- Daimi bir narahatliq vəziyyəti

- əldə əsmə hərəkət qabiliyətində məhdudiyyət

- Fokus va yuxu problemləri

- Bəzi hallarda insanmiya və ya tez-tez kabuslarla gündüz tez-tez yuxusuzluq

- Həzm sistemi ilə bağlı problemlər

- Sürətli ürək dərəcəsi

- Yüksək tərləmə dərəcəsi,

- Daim həyəcan vəziyyətində olmaq

- İnsanın narahatlıqdan qurtulacaq vəziyyətlərdən qaçdığı və narahatlı̆̆ haqlı tapdiğ 1 vəziyyət

- İnsanın həyəcan səbəbiylə vəsvəsələri yatırmaq üçün daima həyata keçirdiyi ritualların meydana gəlməsi.

DSM-4-ə görə ümumiləşdirilmiş narahatlıq pozuqluğu diaqnoz meyarları aşağıdakılardır;

- “On azı altı aylıq dövrün əksər günlərində bəzi hadisələr və ya fəaliyyətlər (məsələn, işdə və ya məktəbdə uğur qazanma bacarığı) ilə əlaqədar həddindən artıq narahatlıq və aldanma (həyəcanla gözləmə) var.

- Şəxs öz xəyallarını idarə etməkdə çətinlik çəkir.

- Bu narahatlıq və aldanma aşağıdakı altı simptomdan üçü (və ya daha çoxu) ilə müşayiət olunur. (Son altı ayın əksər günlərində bəzi simptomlar aşkar edilmişdir)

1. Sakitləşə bilməmək (narahatlıq), gərgin və ya daim kələ-kötürlükdə 
olmaq.

2. Asan yorğunluq.

3. Diqqəti cəmləşdirmək və ya düşüncəni boşaltmaqda çətinlik.

4. Asanliqla qəzəblənmək.

5. Ozələ gərginliyi.

6. Yuxu pozğunluğu (yuxuya getmək və ya yuxunu qorumaq çətinliyi və ya rahat olmayan yuxu).

Anksiyete, xəyal və ya somatik simptomlar sosial, işlə əlaqəli və ya digər vacib funksional sahələrdə klinik cəhətdən narahatlığa və ya funksionallığın azalmasına səbəb olur" [2].

Yüksək həyəcan keçirə biləcək insanlar:

Bəzi insanlar müxtəlif səbəblərdən narahatlıq (narahatlıq pozuqluğu) xəstəliyinə daha çox meylli ola bilərlər. Bu səbəblər tibb dünyasında risk faktorları olaraq adlandırılır. Yüksək həyəcan və ya narahatlıq pozğunluğundakı risk faktorları aşağıdakı kimi sadalana bilər:

1. Anksiyete pozulması, tez-tez depressiya yaşayan bir insanda meydana çıxma ehtimalı daha çox olan bir sağlamlıq problemidir.

2. Maddə asılılığı kimi vəziyyətlərə, sözügedən maddəni tapa bilməmək kimi narahatliqlar səbəb olur.

3. Uşaqlıq dövründə yaşanan sui-istifadə halları

4. Uşaqlıqdakı sosial travmalar insanın narahatlıq səviyyəsində fobiya inkişafina səbəb ola bilər.

5. Genetik meylin müəyyən bir səviyyəsi də psixoloqlar və psixiatrların müzakirə etdiyi bir amildir. Ailənizdə bu cür təcrübə yaşamış insanlara onu artıran risk faktorlarını öyrənmək üçün müraciət edə bilərlər.

Qeyd: Risk faktorları "bu faktorlara sahib insanlar birbaşa Yüksək həyəcan yaşayır " demək deyil.

\section{Yüksək həyəcan növləri hansılardır?}

Hər bir narahatlıq pozğunluğunu müalicə etmək üçün psixoloqlar və psixiatrlar tərəfindən fərqli psixoterapiya metodlarından istifadə edilə bilər.

Sosial narahatlıq: Sosial narahatlıq pozğunluğu, kollektiv bir məkanda oturmaq, xalqın qarşısında danışmaq, dostluq etmək, yeni birisi ilə tanış olmaq və ya bilinməyən bir yerdə olmaq ilə əlaqəli sıx və funksional pozğunluqlar olaraq təyin olunur.

Ayrılma narahatlı̆̆ı: Ayrılma narahatlığının kökü, həm müasir psixologiya, həm də Fredien psixologiyasında valideynlə əlaqələr kontekstində axtarılır. Birinin insanı tərk edəcəyi, insanların insana xəyanət edəcəyi və ya kiməsə və ya bir qrupa sağlam olmayan bir bağlılığa səbəb olacağı ictimai münasibətləri tamamilə önləyəcək bu pozğunluq, qaçınılması lazım olan ciddi bir problemdir.

Xüsusi fobiyalar: Bəzi obyektlərin və ya vəziyyətlərin s1x funksional olmayan qorxularına fobiya deyilir. Həqiqi fobisi olan bir şəxs, sözügedən 
vəziyyət haqqında düşünmək, onu ifadə etmək, sözügedən vəziyyəti əks etdirən bir görünüşə baxmaq üçün dözümsüzdür və səhv müalicələr fobiyanı daha da artırır.

Ümumiləşdirilmiş narahatlıq: Öz həyatından, həyat axınından, gələcəyindən və bu günündən bəri davamlı narahatlıq keçirdiyinə görə həyatını davam etdirə bilən funksionallıqdan uzaq bir insanın vəziyyətidir.

Panik hücum: Qəfildən inkişaf edən və çox vaxt ürək böhranı ilə səhv düşən panik atak problemi, heç bir fiziki stimul olmadığı təqdirdə də sıx psixoloji stimullar səbəbindən meydana gələ bilər.

\section{Anksiyete müalicə üsulları nədir?}

Dinamik psixoterapiya: Müalicənin təməli münaqişə həllidir; disfunksiya əlaqələri, tənzimləmə pozğunluğuna qarşı müdafiə tədbirləri görülür.

Dəstəkləyici psixoterapiya: ekoloji stresin və deqradasiyanın azaldılması

Onlara səbəb olan problemli vəziyyətləri düzəltmək üçün səylər göstərilir.

Koqnitiv Bihevioral Terapiya (CBT): Bilişsel quruluş, psixoloji təlim, rahatlama, nəfəsə nəzarət təmin etmə, qarş1durma, praktik təhlil, rəhbərlik özünütəhsil daxildir. "Koqnitiv xəstəliklər səbəb olan idrak terapiyası narahatlıqları daha real görməyə imkan verir və bu şəkildə daha yaxşı planlaşdırma narahatlığı azalda bilər. Yoxlamağın yollarını göstərir. Xəstələr eyni zamanda "narahatlıqdan narahat olmaq" narahatlı̆̆ gəlmək problemləri həll etmək üçün iş üsulları. Onlar da bunun olmadığını başa düşürlər" [3].

$\mathrm{Bu}$ gün Koqnitiv və Bihevioral terapiyanın birlikdə istifadə olunduğu psixoterapiyanın daha çox faydası təmin etdiyi ifadə edildi. Tədqiqatın psixodinamikası Koqnitiv-Bihevioral terapiya Psixoterapiyadan [4] və farmakoterapiyadan daha təsirli olduğunu göstərər.

Narahatlıq keçirən insan ətrafı təhdid edir. Otraf mühit stimullarını təhlükə istiqamətində qəbul edir, şişirdir, ümumiləşdirir. Özü onlarla mübarizəaparacaq qədər güclüdür və narahatlıqla mübarizə zamanı potensial yardım sə-lahiyyətləri qiymətləndirmir. [5] Bu səbəbdən kimin narahatlığ 1 var insanlarda ən əsas idrak sxemləri təhlükə, təhdid və zəiflikdir.

\section{Odəbiyyat:}

1. Klinik psikolog Didem Tepret, 20 may, 2020

2. E. DSM-IV-TR tanı ölçütleri başvuru el kitabı. Hekimler Yayın Birliği, Ankara, 2001.

3. Butler G, Fennell M, Robson P, Gelder M. Comparison of behavior therapy and cognitive behavior therapy in the treatment of generalized anxiety disorder. J Consult Clin Psychol 1991; 59: 167-75 
4. Butler G, Fennell M, Robson P, Gelder M. Comparison of behavior therapy and cognitive behavior therapy in the treatment of generalized anxiety disorder. J Consult Clin Psychol 1991; 59: 167-75

5. Fenton GW: Recent advances in the study of anxiety. Roth M, Noyes RJr, Burrows GD (eds.): Handbook of Anxiety, Vol: 1, Elsevier Science Publishers, Amsterdam, 1988: 399-419 